\title{
Reflexões sobre a atuação profissional dos turismólogos e o planejamento do turismo: pesquisa com os egressos dos Cursos de Turismo de Curitiba, Paraná, Brasil
}

\section{Considerations on Tourism Graduates professional activity and tourism planning: a research with Curitiba, Paraná, Brasil tourism higher education egress}

\author{
Juliana Medaglia (MEDAGLIA, J.) ${ }^{*}$ \\ Carlos Eduardo Silveira (SILVEIRA, C. E.) ${ }^{* *}$
}

\begin{abstract}
RESUMO - Esse artigo apresenta os resultados de uma pesquisa realizada com os egressos de cursos de bacharelado em Turismo de Curitiba, cujo objetivo foi comparar as expectativas que possuíam os turismólogos na época em que estudavam e suas atividades vigentes. A pesquisa quantitativa foi disponibilizada on line utilizando a ferramenta form do Google Docs, com amostra de 215 questionários válidos, respondidos entre fevereiro e março de 2009. Assim, apresenta-se um perfil básico da amostra, passando para a situação profissional logo após a colação de grau e a atuação em Planejamento Turístico, dos que partiram para essa área. De maneira geral, concluiu-se que a participação do turismólogos no mercado tendeu a ser mal remunerada e que a atuação dos mesmos no Planejamento Turístico foi discreta e acumulada com alguma outra atividade.
\end{abstract}

Palavras-chave: Planejamento Turístico; Atuação Profissional de Turismólogos; Ensino Superior de Turismo; Mercado de Trabalho; Cursos de Turismo em Curitiba.

ABSTRACT - This article presents the results of a research carried out with egress from Tourism courses located in Curitiba that aimed to compare their expectations during their undergraduate studies with their current professional activities. The quantitative research was released on line using the form toll from Google Docs, with a sample of 215 valid questionnaires, answered in February and March 2009. This way, it is showed a basic profile of the sample, moving to the professional situation right after the graduation and the professional involvement with Tourism Planning, of those who embraced this area. It can be concluded that the participation of these professionals in the labour market tends to be badly paid and that their participation in Tourism Planning is discreet and often shared with another professional activity.

Key words: Tourism Planning; Professional Activity for Tourism Graduates; Tourism Higher Education; Labour Market; Undergraduate Tourism Courses in Curitiba.

\footnotetext{
* Graduação em Turismo pela Universidade Anhembi Morumbi (1998). Especialização em Marketing Empresarial pela Universidade Federal de Santa Catarina (2002). Mestrado em Comunicación y Turismo pela Universidad de Malaga/Espanha (2005), além de Especialização em Gestão Social pela Universidade Positivo - UP (2008). Professora do Departamento de Turismo da Universidade Federal dos Vales do Jequitinhonha e Mucuri - UFVJM, em Diamantina/MG. Endereço para correspondência: Universidade Federal dos Vales do Jequitinhonha e Mucuri - UFVJM (Campus JK - Bloco 5 - Gabinete 7). Rodovia MGT 367 - Km 583, n. 5000 (Alto da Jacuba). CEP: 39100-000 - Diamantina - Minas Gerais (MG/Brasil). Telefones: +55 (38) 3532-1200 / 3532-6000. E-mail: julianamedaglia@hotmail.com

** Graduação em Turismo e Hotelaria pela Universidade do Vale do Itajaí (1994). Mestrado em Tourism in Developing Countries - University of Strathclyde/Escócia (2001) e Doutorado em Gestión y Desarrollo Turístico Sostenible na Universidad de Málaga/Espanha (2004). Professor do Departamento de Turismo da Universidade Federal dos Vales do Jequitinhonha e Mucuri - UFVJM, em Diamantina/MG. Endereço para correspondência: Universidade Federal dos Vales do Jequitinhonha e Mucuri - UFVJM (Campus JK - Bloco 5 - Gabinete 7). Rodovia MGT 367 - Km 583, n. 5000 (Alto da Jacuba). CEP: 39100-000 Diamantina - Minas Gerais (MG/Brasil). Telefones: +55 (38) 3532-1200 / 3532-6000. E-mail: caesilveira@hotmail.com
} 


\section{INTRODUÇÃO}

Este artigo surge no âmago da curiosidade científica acerca do ensino da disciplina de Planejamento Turístico. Os autores já foram professores da referida disciplina e um deles aprofundou estudos sobre a temática em seu doutorado. É importante salientar também que no âmbito da educação superior de turismo a disciplina Planejamento Turístico já era compulsória em 1971, quando o Ministério de Educação (Brasil) controlava mais firmemente os programas superiores. Na esfera pública em geral cabe colocar ainda que o planejamento enquanto estratégia de ação possui destaque nas Políticas Públicas Nacionais através dos programas lançados pelo Governo Federal.

Assim, a constante leitura acerca do tema relacionada ao ensino da disciplina, somada ao fato de que o Planejamento Turístico é considerado uma das principais áreas de atuação profissional dos bacharéis em turismo no Brasil (ALMEIDA, 2005, p. 67), e ainda avaliando ser este um tema comum em quase todos os programas de turismo no país, apresenta-se neste artigo uma pesquisa que teve como objetivo identificar a situação profissional do bacharel em turismo, com especial ênfase nos profissionais interessados em Planejamento Turístico considerando-se como problema de pesquisa a verificação do nível de inserção profissional desses egressos em sua área de interesse e sua satisfação em relação à área de atuação. Ao considerar a dificuldade de se conhecer a realidade do ensino superior de Turismo no que tange ao planejamento turístico em nível nacional, optou-se não somente por selecionar um universo, mas também por um âmbito geográfico factível de ser investigado, porém representativo da realidade. Assim, a pesquisa aconteceu na cidade de Curitiba, capital do estado do Paraná (PR), Brasil, localidade na qual o Planejamento Turístico constava como conteúdo em todos os programas dos cursos superiores de turismo preliminarmente analisados.

O artigo apresenta um referencial teórico que aborda o Planejamento Estratégico de Destinos e sua relação com o ensino do Planejamento Turístico. Em seguida nele se apresentam gráficos e resultados que oferecem elementos para estudos correlatos e posteriores. 


\section{PLANEJAMENTO ESTRATÉGICO DE DESTINOS E O PAPEL DOS TURISMÓLOGOS}

Ainda que planejar seja uma prerrogativa humana em todos os aspectos, as primeiras áreas a consolidar teorias sobre planejamento foram a militar e a econômica. Mintzberg (1999) menciona que já havia referência a um diretor de Planejamento Estratégico no livro Arte da Guerra de Sun Tzu, escrito a mais de 2.400 anos. Segundo Barretto (2005) da linguagem militar se guardam os conceitos de estratégia e tática. Para Calduch Cervera (1993) a estratégia bélica pode ser definida como o conjunto de decisões e atuações que adota todo beligerante com o objetivo de planejar, organizar e utilizar o poderio disponível e alcançar os objetivos militares e os fins políticos da guerra do modo mais eficaz possível. A tática, em contrapartida, está formada pelo conjunto de decisões e atividades militares destinadas a alcançar o sucesso em cada uma das batalhas, seguindo os planos elaborados pela estratégia bélica.

Na esfera econômica, no século passado, o primeiro governo a utilizar planos estratégicos qüinqüenais nos anos 1920, passando para sete em sete anos nos anos 1930, foi o governo Soviético (BARRETTO, 2005) e Mintzberg (1999) menciona que, ironicamente, começa a se popularizar na América corporativa, nos anos 1950 como exercício orçamentário. Nos anos sessenta quando começam a se observar mudanças relativamente rápidas e freqüentes nos mercados, é criada a necessidade de ajustar a atividade empresarial interna à natureza do entorno, caracterizando o planejamento estratégico empresarial (MUNUERA ALEMÁN; RODRÍGUEZ ESCUDERO, 1998). Até então, as atividades produtivas possuíam seu foco nelas mesmas, sem considerar o que atualmente se entende como entorno, ou seja, as forças externas que poderiam influenciar o desempenho das empresas. Pode-se dizer que tal entorno apresentava um âmbito relativamente pequeno se comparado ao que se aprecia atualmente. Considerações acerca do entorno natural, da ética empresarial, da gestão de recursos humanos, da qualidade, das necessidades e desejos de consumidores, dos avanços tecnológicos, entre outros; ainda não faziam parte do universo empresarial. Até esse período o planejamento existia, mas na simplicidade de se traçar ou descobrir um curso de ação para obter um objetivo desejado. 
Assim, o planejamento estratégico nasce, no eixo ocidental, no âmbito empresarial, mas seu êxito ao considerar o entorno no exercício do planejamento faz com que ele seja aplicado em outros campos. A Organização Mundial do Turismo OMT (1999) aponta que é no princípio dos anos oitenta que se incorpora o planejamento (estratégico) na esfera pública, sendo aplicado nos espaços urbanos, metropolitanos e regionais; assentando-se progressivamente como um método para a gestão das mudanças, em direção à criação de um futuro melhor dentro das possibilidades, tanto das organizações, como das comunidades ou setores específicos dentro de tais áreas.

O fato de o planejamento estratégico considerar o entorno como variável de planejamento é de grande utilidade para o turismo, uma vez que a atividade pode ser considerada um sistema com fortes influências e participações externas (BENI, 2001). A partir destas inter-relações, é importante que o planejamento turístico tenha como objetivo o desenvolvimento integrado de todas as partes do sistema, tanto considerando a demanda quanto a oferta, como os elementos físicos e institucionais (INSKEEP, 1991 apud VALLS, 2000) ${ }^{1}$.

A importância do planejamento integral está em seu valor para a resolução de potenciais conflitos sobre o uso de certos recursos, de maneira a atender tanto as necessidades da comunidade de um local como as dos turistas, já que permite considerar as implicações do setor turístico em termos econômicos, sociais e ambientais.

Entre os traços que caracterizam o planejamento estratégico aplicado ao desenvolvimento turístico, a Organização Mundial do Turismo estabelece que a terminologia usada para o Plano de Desenvolvimento Turístico, é na verdade um plano estratégico que integra todos os aspectos do desenvolvimento turístico (OMT, 1998).

Entretanto, o trabalho de coordenação com vistas a um planejamento estratégico sustentável de destinos exige mais que planos integrados entre empresas e destinos, políticas públicas e participação da sociedade. Torna-se essencial uma conscientização dos agentes turísticos acerca da necessidade de objetivos gerais comuns, que serão desenvolvidos no processo de planejamento. A atuação dos profissionais responsáveis pela coordenação desse processo e do equilíbrio entre todos esses interesses pode estar relacionada à formação adequada que se considera disponível nos cursos de Turismo.

\footnotetext{
${ }^{1}$ INSKEEP, E. Tourism Planning: an integrated and sustainable development approach. Toronto: John Wiley \& Sons, 1991.
} 
Esta formação por sua vez depende em grande parte do corpo docente e sua visão sobre o turismo e sobre o planejamento turístico. Na verdade, segundo Spinelli (2002, p. 118) esta influência vai além. A autora afirma que:

\begin{abstract}
A evolução pessoal dos profissionais do turismo será fortemente influenciada pelas características pessoais de seus educadores; a filosofia de vida, a visão de mundo dos professores, os conteúdos transmitidos deixarão marcas importantes nos processos evolutivos dos futuros profissionais do turismo.
\end{abstract}

Neste âmbito, julga-se pertinente mencionar que os presentes autores deste trabalho já realizaram uma pesquisa anterior com os professores da disciplina de Planejamento Turístico da cidade de Curitiba ${ }^{2}$, obtendo-se como uma das principais conclusões o baixo interesse dos egressos pela atuação na área.

\title{
3 PLANEJAMENTO TURÍSTICO COMO DISCIPLINA E A CARREIRA DO BACHAREL EM TURISMO
}

Há uma quantidade crescente de literatura relacionada ao ensino do Turismo, inclusive no Brasil, onde habitualmente os eventos da área possuem Grupos de Trabalhos (GTs) dedicados ao ensino do Turismo, tendo a formação e a atuação profissional de turismólogos figurado como tema principal do Congresso Brasileiro de Turismo - CBTUR, de 2002 e do Congresso Brasileiro de Docência e Pesquisa em Turismo na Faculdade Cenecista Presidente Kennedy, em Campo Largo (PR) no mesmo ano. Publicações internacionais recentes, como a de Airey e Tribe (2005), tratam do ensino do turismo e suas interfaces com o mercado de trabalho e o próprio Libro Blanco del Turismo, organizado por Ministral sob encomenda para a Agencia Nacional de Evaluación de la Calidad y Acreditación - ANECA (2005) na Espanha. Matias (2005) demonstra com profundidade a relação da formação profissional e universitária em turismo com o mercado de trabalho e Machado (2006) apresenta um estudo acerca da inserção profissional de egressos de um dos cursos superiores de Turismo de Belo Horizonte (MG).

\footnotetext{
${ }^{2}$ Para mais informações vide: SILVEIRA, C. E.; GÂNDARA, J. M. G.; MEDAGLIA, J. A disciplina de Planejamento Turístico no Ensino Superior de Turismo: das influências aos novos desafios. Revista Brasileira de Pesquisa em Turismo, v. 2, n. 1, p. 113-133, mar. 2008.
} 
Uma constatação evidenciada é a de que ainda que o Planejamento Turístico seja uma das áreas mais consolidadas no ensino do turismo, como mencionado já no início deste artigo são muito escassas as publicações especificamente sobre o ensino dessa área em disciplinas de cursos superiores em turismo, e menos ainda a respeito da inserção profissional do Turismólogo como Planejador de Turismo, o que levou os autores deste artigo a realização da pesquisa que se apresenta a seguir.

\section{APRESENTAÇÃO E METODOLOGIA DA PESQUISA}

A pesquisa que se segue não partiu de hipóteses pré-estabelecidas, sendo, portanto, do tipo exploratória, baseada no método dedutivo, por buscar na teoria e nos dados a explicação para a realidade observada (DENCKER, 2007 e OMT, 1998).

Para a obtenção dos dados empíricos, procedeu-se à realização de uma pesquisa quantitativa que teve como universo os egressos de cursos superiores em Curitiba, cujo número estimado oscilava na época entre 3.500 e 5.000 turismólogos e que pode ser considerado, segundo Rea e Parker (2002) como uma população pequena. Realizou-se um Web Survey ${ }^{3}$ utilizando o recurso form ${ }^{4}$ do Google Docs ${ }^{\circledR}$, disponibilizado on line entre 10 de fevereiro de 2009 e 20 de março do mesmo ano, totalizando 215 formulários válidos, o que dentro de um nível de confiança de 99\%, coloca a margem de erro entre $5 \%$ e 10\%. A proposta foi a de criar um instrumento de rápida aplicação e fácil compreensão, que foi testado com 20 bacharéis em turismo de outro Estado brasileiro a fim de ajustá-lo. As respostas obtidas foram tabuladas em planilhas de cálculo do MS Excel ${ }^{\circledR}$ com os cruzamentos realizados pela ferramenta de Tabela Dinâmica, de forma discricionária com base nos interesses relativos ao problema da pesquisa, que buscava identificar não somente a atuação profissional dos egressos de bacharelados em Turismo da cidade de Curitiba, mas mais especificamente sua atuação na área de Planejamento Turístico.

O formulário final, além de nome ou pseudônimo, e-mail (endereço eletrônico) dos interessados em receber os resultados e espaço para comentários, contou com 17

\footnotetext{
${ }^{3}$ Enquete disponibilizada via internet que permite que os respondentes preencham os dados acessando diretamente o formulário e o enviem ao pesquisador para tabulação de forma facilitada.

${ }^{4}$ Ferramenta do Google que cria gratuitamente formulário para preenchimento pelos respondentes.
} 
perguntas. Destas somente 4 eram abertas; sendo outras 6 semi-abertas - de múltipla escolha, mas com a opção 'outros'; 7 fechadas divididas em 1 dicotômica, 4 de múltipla escolha excludentes e 2 de escala de Lickert com respostas entre 1 e 5 , sendo este último o menor grau de concordância. A estrutura deste instrumento de pesquisa foi ainda dividida em três blocos, a saber: I) Perfil Profissional; II) Perfil quando RecémFormado e III) Atuação em Planejamento Turístico.

\section{BLOCO I - PERFIL PROFISSIONAL}

Os gráficos apresentados na sequência trazem os dados levantados pelo web survey, sendo o foco neste primeiro bloco voltado para o conhecimento do perfil profissional dos egressos dos bacharelados em Turismo de Curitiba, levando em conta não somente o local de graduação, mas também sua formação continuada.

Como pode ser percebida no primeiro gráfico, a amostra foi composta principalmente por egressos da Universidade Federal do Paraná - UFPR e da Universidade Positivo - UP, seguida por considerável equilíbrio entre a Pontifícia Universidade Católica do Paraná - PUC, a Universidade Tuiuti do Paraná - UTP, a das Faculdades Santa Cruz e a do Centro Universitário Curitiba - UNICURITIBA. As outras Instituições de Ensino (IES) apresentaram representatividade mais discreta, sendo maior a da Faculdades Integradas do Brasil - UNIBRASIL, e tendo por fim novo equilíbrio entre Faculdade Internacional de Curitiba - FACINTER, Faculdade Metropolitana de Curitiba - FAMEC, Grupo Educacional Opet - OPET e Centro Universitário Campos de Andrade - UNIANDRADE.

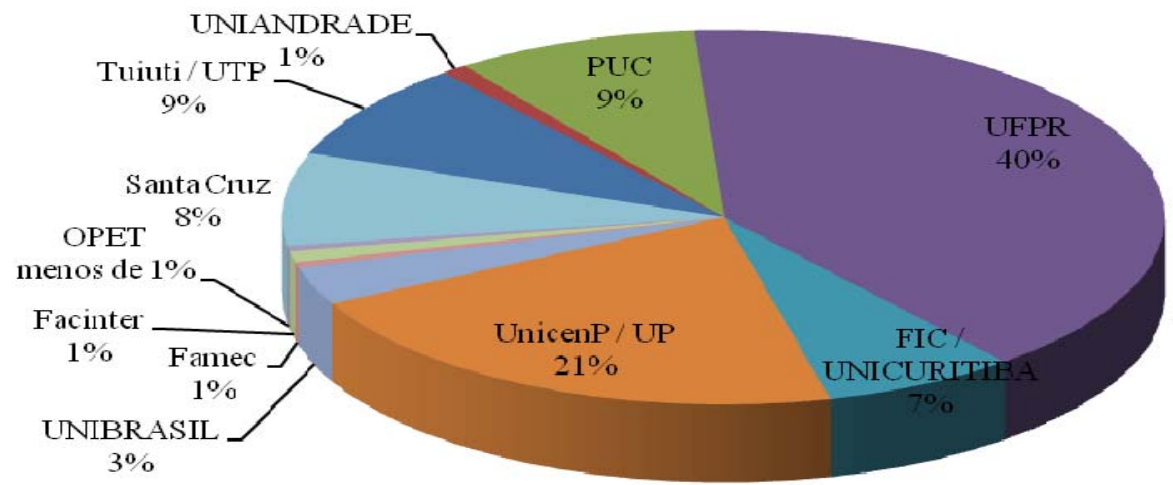

GRÁFICO 1 - IES DE ORIGEM DA AMOSTRA POR PERCENTUAIS FONTE: WEB SURVEY, 2009. 
De fato os cursos que mais tiveram representantes foram os que mais formavam turismólogos em Curitiba na época, sendo a UP (21\%) no setor privado e a UFPR (40\%) do setor público, esta última com o curso mais tradicional e antigo do Estado. As demais ficaram com um percentual abaixo de $10 \%$ cada uma.

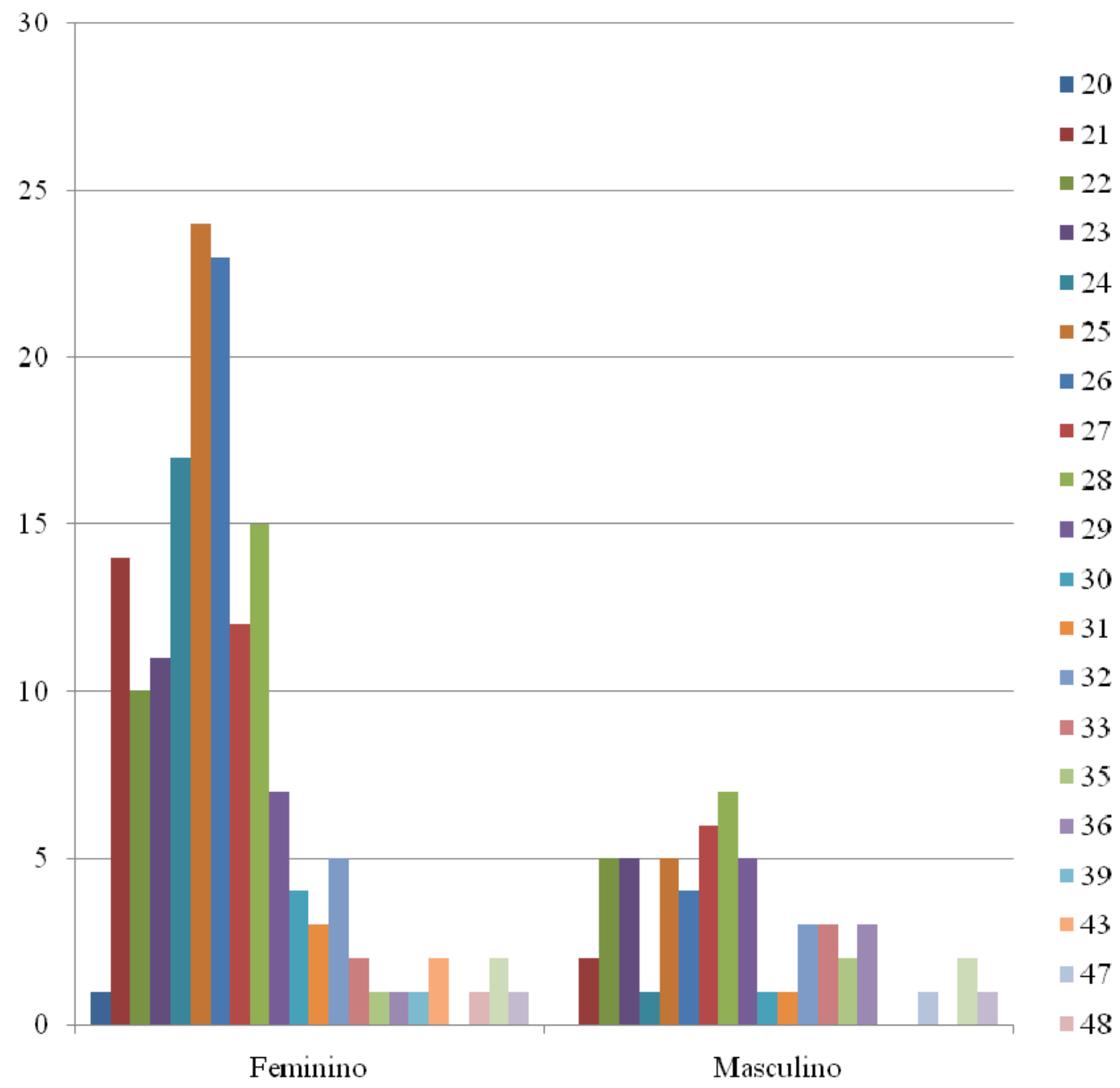

GRÁFICO 2 - AMOSTRA POR SEXO E FAIXA ETÁRIA FONTE: WEB SURVEY, 2009.

Aqui se confirmou o consenso de que os cursos de Turismo são predominantemente procurados por estudantes do sexo feminino, sendo $73 \%$ da amostra. Além disso, a concentração de egressos na faixa entre 21 e 28 anos de idade representou 74\% da amostra, e apontou para um grande número de jovens recémformados nos últimos anos na área. 


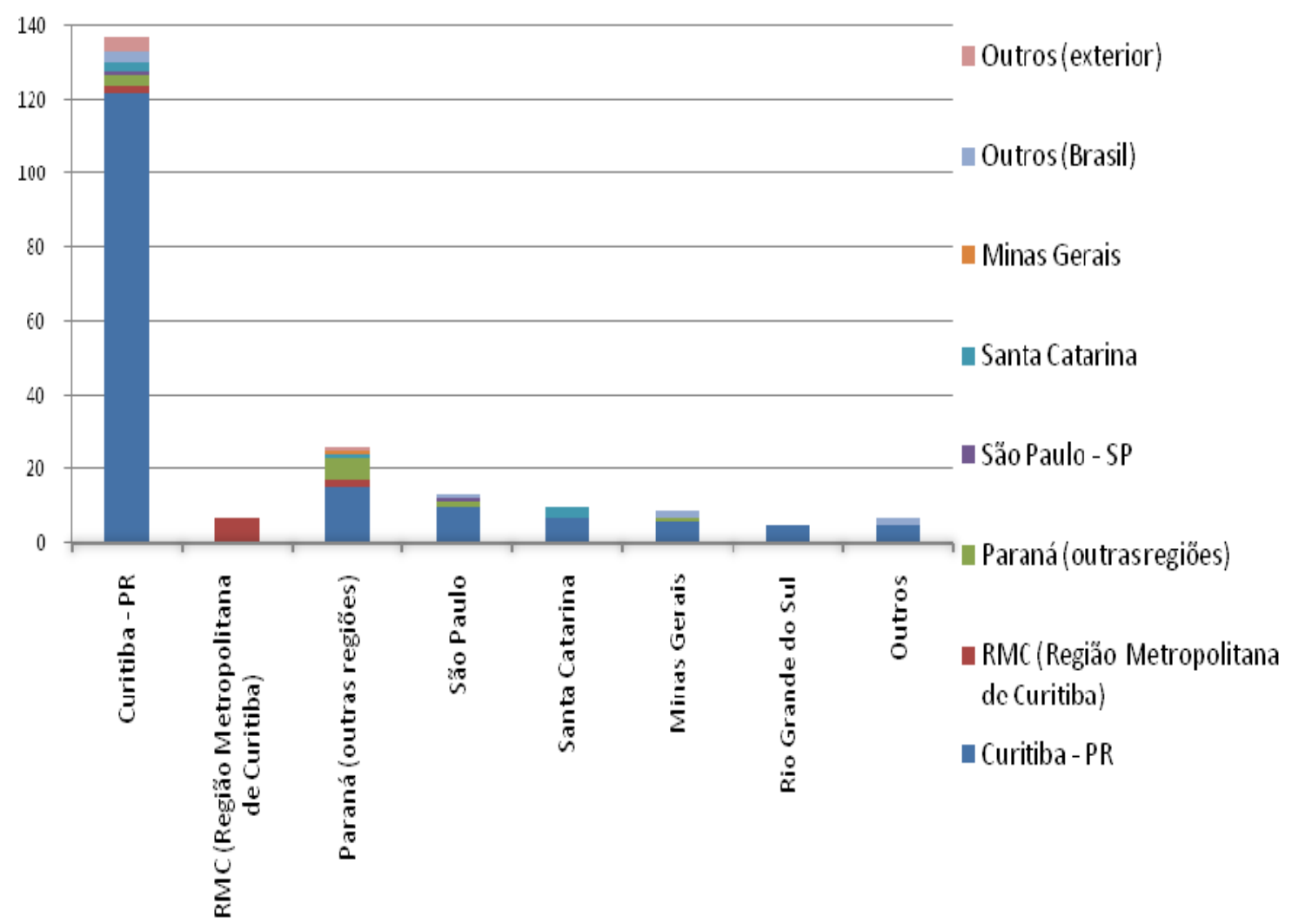

GRÁFICO 3 - ORIGEM E RESIDÊNCIA DOS EGRESSOS FONTE: WEB SURVEY, 2009.

O gráfico anterior apresenta uma combinação de critérios demonstrados no eixo horizontal de onde eram originalmente as pessoas que estudaram turismo em Curitiba, agrupados por recorrência de respostas, e, na legenda, onde residiam, após a conclusão do curso, na época da pesquisa. A grande maioria dos respondentes (137) era originalmente de Curitiba, e poucos deles (15), saíram da cidade depois de formados. Já dos que vieram de fora para estudar em Curitiba, poucos voltaram as suas origens ou migraram para outras regiões, sendo o dado que mais chamou a atenção é que a maioria dos que vieram de fora para estudar em Curitiba, permaneceu na cidade depois de formado, totalizando $62 \%$ da amostra. Entre os curitibanos o percentual que permaneceu na cidade após a colação de grau chegou a $89 \%$. 


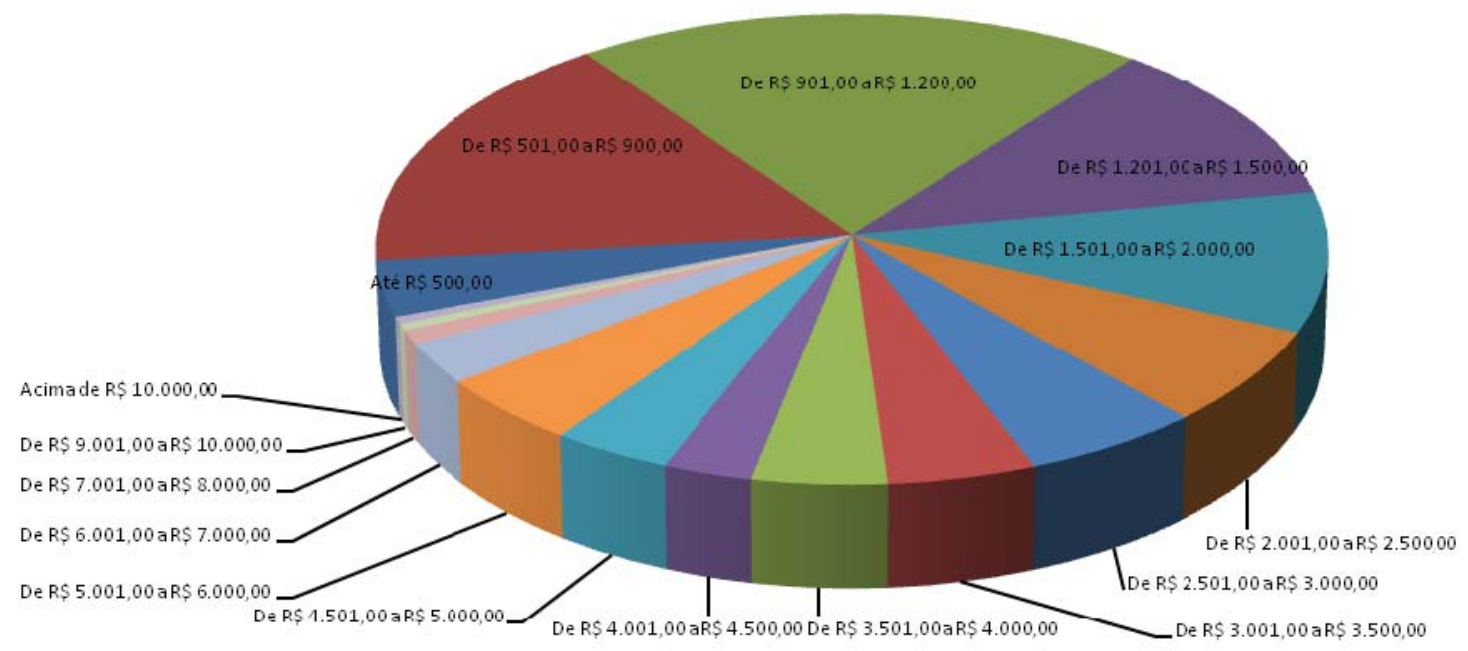

GRÁFICO 4 - FAIXA DE RENDA DOS EGRESSOS FONTE: WEB SURVEY, 2009.

Entre a amostra percebeu-se uma grande tendência a baixos salários, o que pôde ser confirmado quando se somou a quantidade de respondentes que recebiam até $\mathrm{R} \$$ $1.500,00$, o que representou $56 \%$ da amostra. A principal faixa salarial foi a de $\mathrm{R} \$$ 901,00 a R $1.200,00$; menos de $10 \%$ da amostra declarou ter renda superior a $\mathrm{R} \$$ 5.000,00 e somente uma pessoa afirmou receber mais de $\mathrm{R} \$ 10.000,00$ mensais. Como já mencionado, a amostra foi composta principalmente por recém-formados, o que foi analisado no gráfico seguinte.
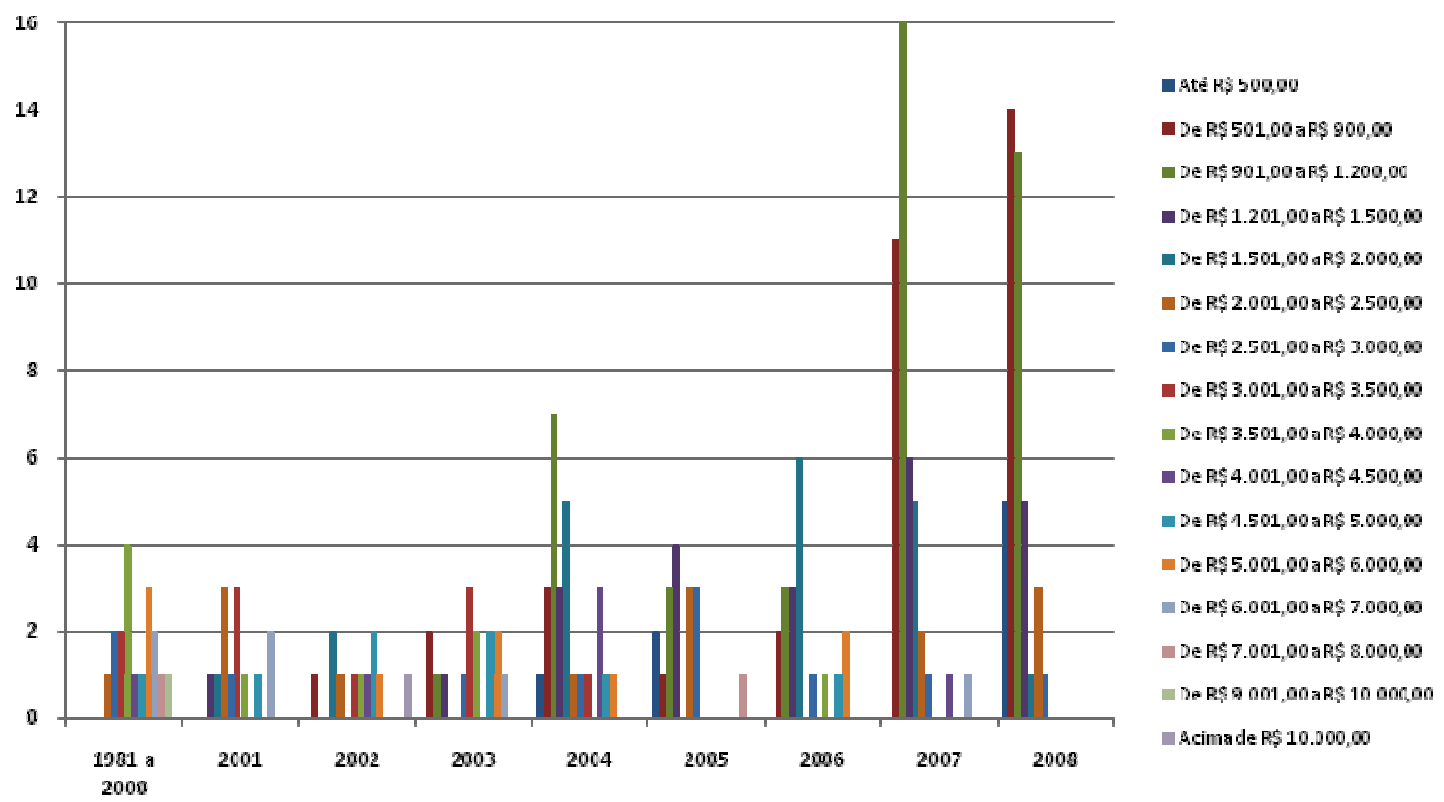

GRÁFICO 5 - FAIXA DE RENDA POR ANO DE FORMATURA FONTE: WEB SURVEY, 2009. 
Percebe-se que o tempo pós-colação de grau influenciou positivamente nos salários, uma vez que apenas 9\% dos formados a partir de 2008 afirmaram ter renda superior a R\$2.000,00 e em contrapartida todos os formados entre 1981 e 2000 afirmaram receber mais de $\mathrm{R} \$ 2.000,00$ por mês, sendo a faixa mais representativa destes (40\%) com faixa salarial acima de $\mathrm{R} \$ 5.001,00$. Considerou-se que a melhoria na remuneração com o passar do tempo de formatura poderia tanto significar que as ofertas de emprego em anos anteriores eram melhores e que essas vagas foram preenchidas por quem se formou antes, quanto denotar que a área ainda levava em conta o tempo de serviço mais do que a formação, ou que pessoas formadas há mais tempo tiveram mais oportunidade de continuar seus estudos e que isso se refletisse em seus salários.

\section{BLOCO II - PERFIL QUANDO RECÉM-FORMADO}

Em relação ao mercado de trabalho de turismólogos, de forma ampla, observouse na pesquisa realizada que a maioria das pessoas (54\%) afirmou que nos primeiros meses de formadas permaneceram onde ou com o que já trabalhavam. Dessas, $43 \%$ já estavam trabalhando na área de turismo quando concluíram seus cursos, o que remete à possibilidade de abertura de mercado advinda dos estágios e à opção por capacitação superior de profissionais já empregados.

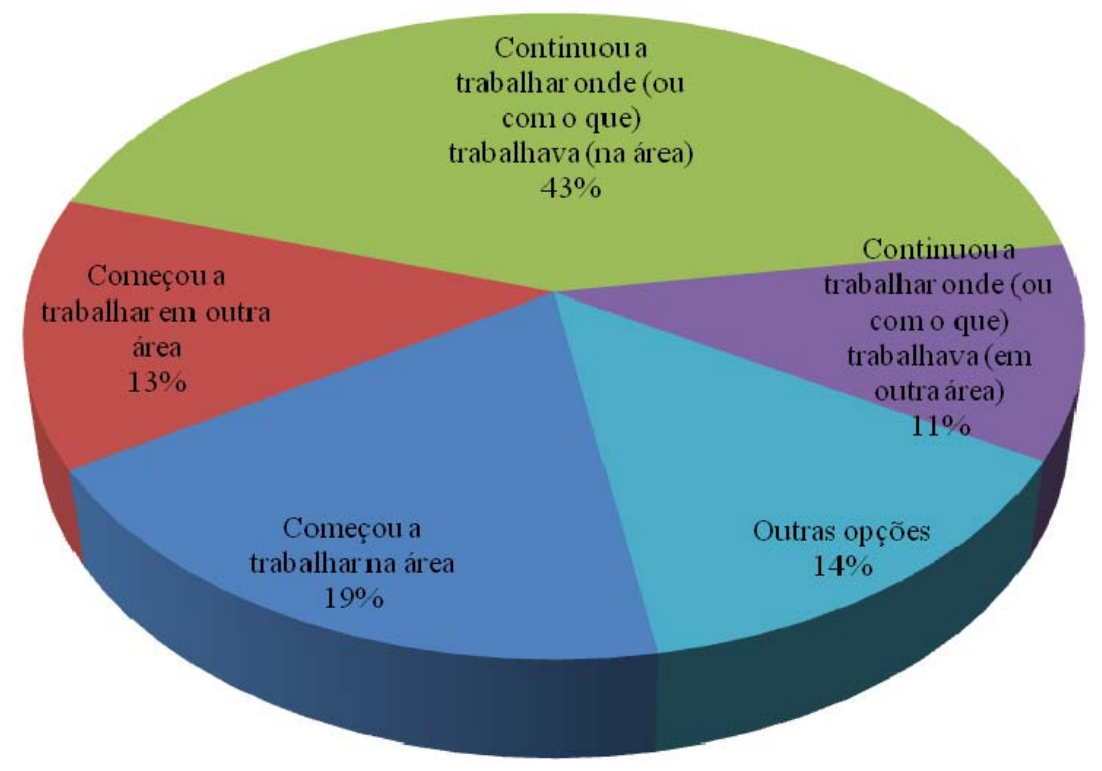

GRÁFICO 6 - OS QUE COMEÇARAM A TRABALHAR OU CONTINUARAM TRABALHANDO FONTE: WEB SURVEY, 2009. 
Foi considerável o número levantado de pessoas que começaram a trabalhar na área logo depois de formadas, perfazendo 19\% da amostra, ainda que a quantidade de pessoas que permaneceu em empregos fora do turismo (11\% dos respondentes) ou que começou a trabalhar em outras atividades (13\%) também apontasse para uma saturação de mercado. O dado mais marcante, entretanto, foi o percentual de 54\% dos respondentes que afirmou ter continuado a trabalhar com o que já trabalhavam antes de concluir o curso superior, dos quais $43 \%$ na área de turismo.

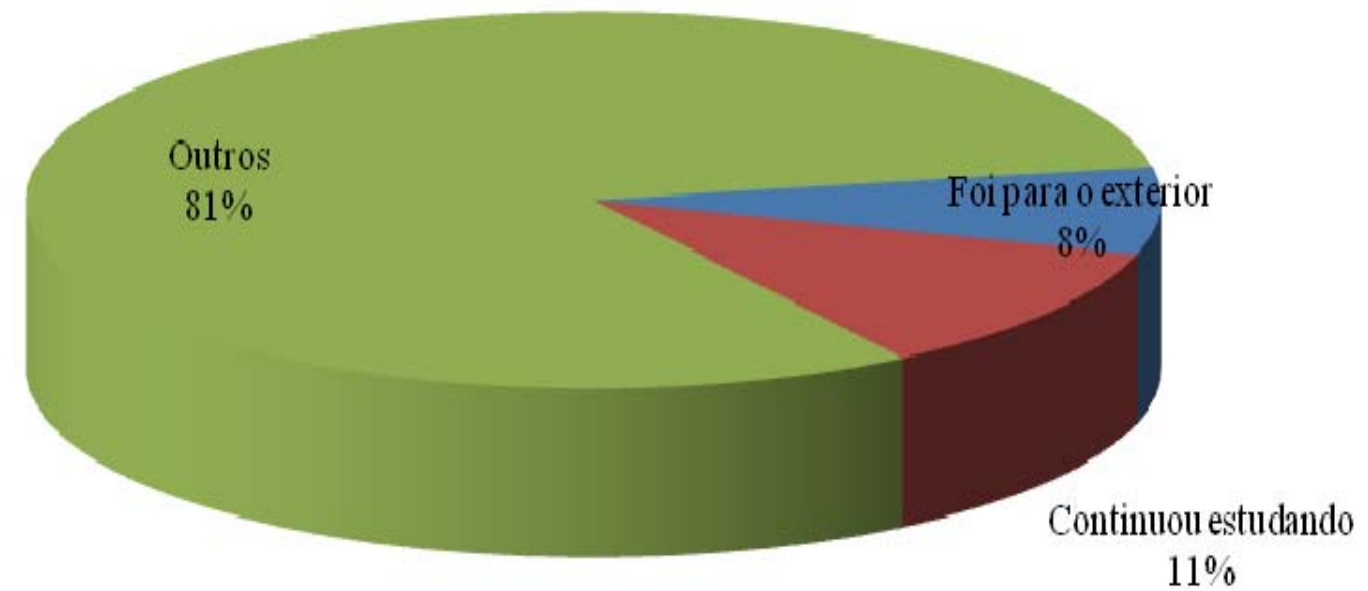

GRÁFICO 7 - CONTINUARAM ESTUDANDO OU FORAM PARA O EXTERIOR FONTE: WEB SURVEY, 2009.

Neste caso pôde-se notar que, já nos primeiros meses de formados, $11 \%$ dos turismólogos continuaram seus estudos, alguns até mesmo partindo para outra graduação, ou que já a cursavam em paralelo. Ainda que a profissão de turismólogo carregue a imagem de ser internacionalizada, somente $8 \%$ da amostra afirmou ter ido para o exterior nos primeiros meses pós-formatura.

Em termos de remuneração, percebeu-se que sua melhoria não ocorreu somente com o tempo de formado, como mencionado antes, mas também, com a continuidade nos estudos, conforme o gráfico a seguir, que agrupa três situações: turismólogos que se formaram e fizeram somente cursos de idiomas, atualização e/ou extensão; os que fizeram outra graduação, mas nenhuma pós-graduação, e a última dos que fizeram pósgraduação incluindo ou não outros cursos. 


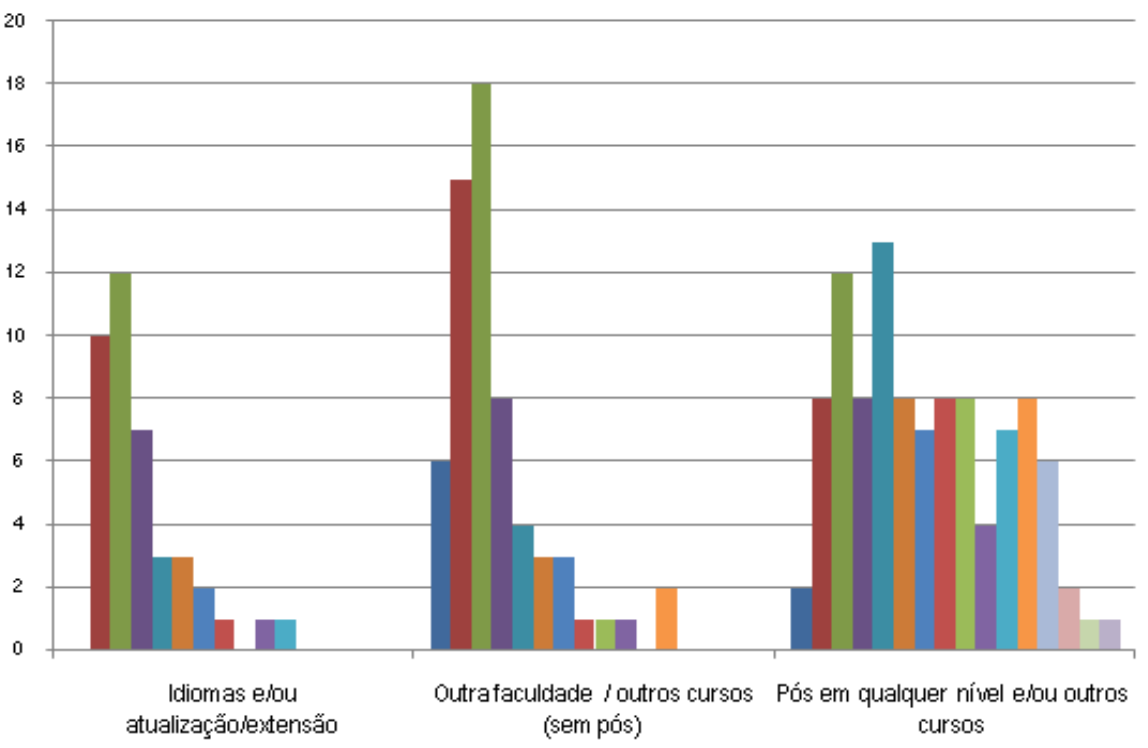

GRÁFICO 8 - RENDA DE ACORDO COM ESTUDOS APÓS A GRADUAÇÃO FONTE: WEB SURVEY, 2009.

Com base nas respostas pôde-se observar que, ainda que houvesse turismólogos que mesmo pós-graduados possuíam baixa remuneração, os dois que declararam maior renda - um deles acima de $\mathrm{R} \$ 9.001,00$ e outro acima de $\mathrm{R} \$ 10.000,00$, ambos possuíam doutorado na área. Isso permitiu a interpretação de que se a qualificação não garante o aumento na remuneração, sua falta impede ou pelo menos dificulta tal aumento. Além disso, a concentração de melhores salários foi maior no grupo de pessoas que continuaram seus estudos, como se verificou em mais detalhes no gráfico a seguir, que considerou o nível mais alto de estudo mencionado pelo respondente depois de concluída sua graduação. As faixas de renda foram representadas em colunas com valores crescendo da esquerda para a direita, e agrupadas por níveis de formação. Eixo vertical representando o número de respondentes. Percebe-se que os grupos de colunas vão diminuindo de altura, ou seja, menor quantidade de respondentes na medida em que a formação vai aumentando. Contudo, com o aumento da formação, mais tende a crescer a remuneração, perceptível na concentração à direita nos grupos de colunas. 


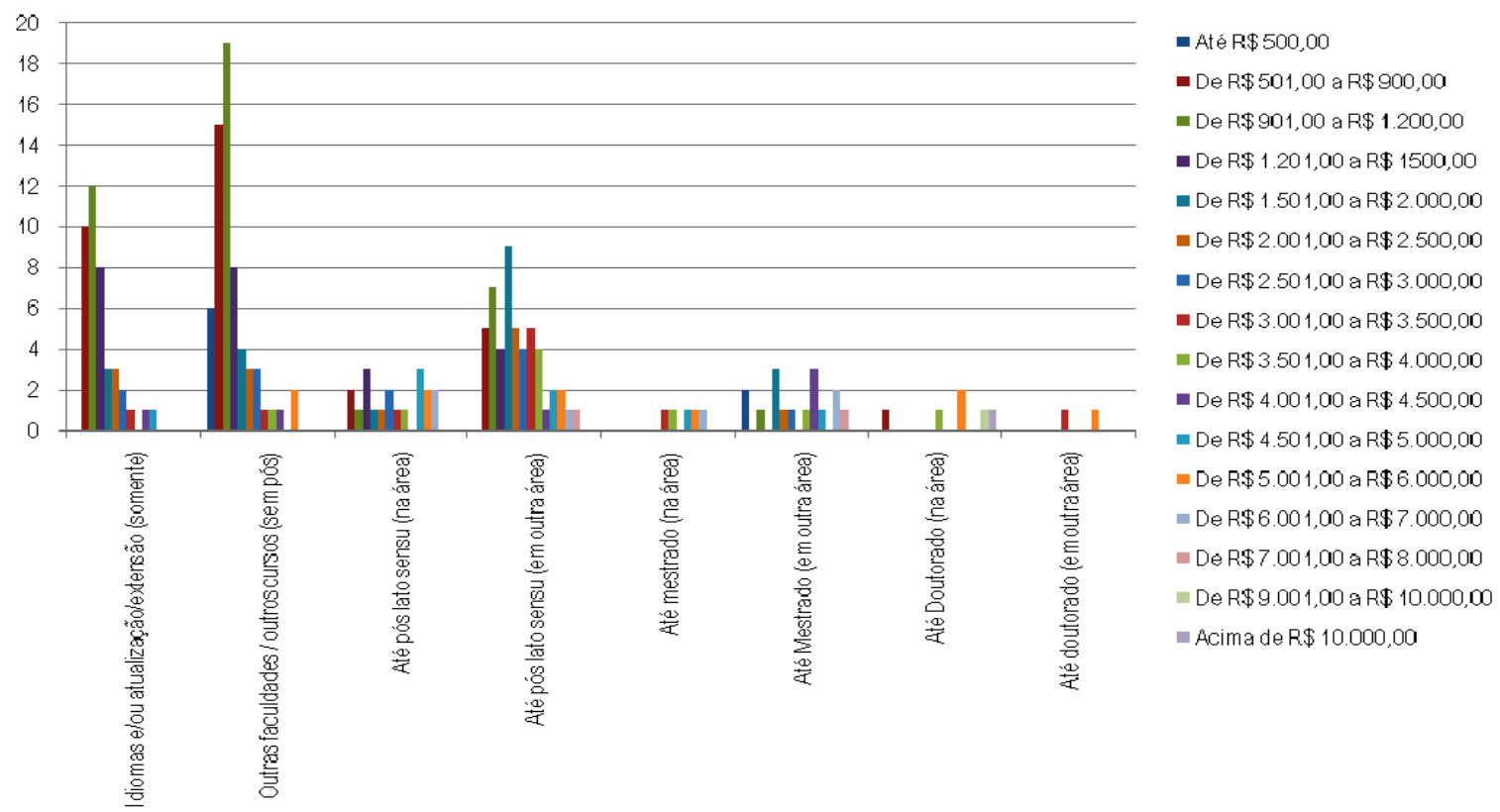

\section{GRÁFICO 9 - FAIXA DE RENDA EM TODOS OS NÍVEIS} FONTE: WEB SURVEY, 2009.

Aqui, indagou-se se os que mencionaram níveis superiores (como doutorado, por exemplo), poderiam ter ou não cursado níveis anteriores (como pós-graduação lato sensu, por exemplo), mas para esta interpretação tais níveis não foram considerados. O que se percebeu nesse desmembramento é que as maiores remunerações, ainda que em menor freqüência, estavam relacionadas aos que tinham maior nível de formação na área, mas que existia uma grande variação de faixas salariais em cada categoria, o que poderia estar indicando um mercado pouco inclinado a vincular a remuneração ao nível de formação.

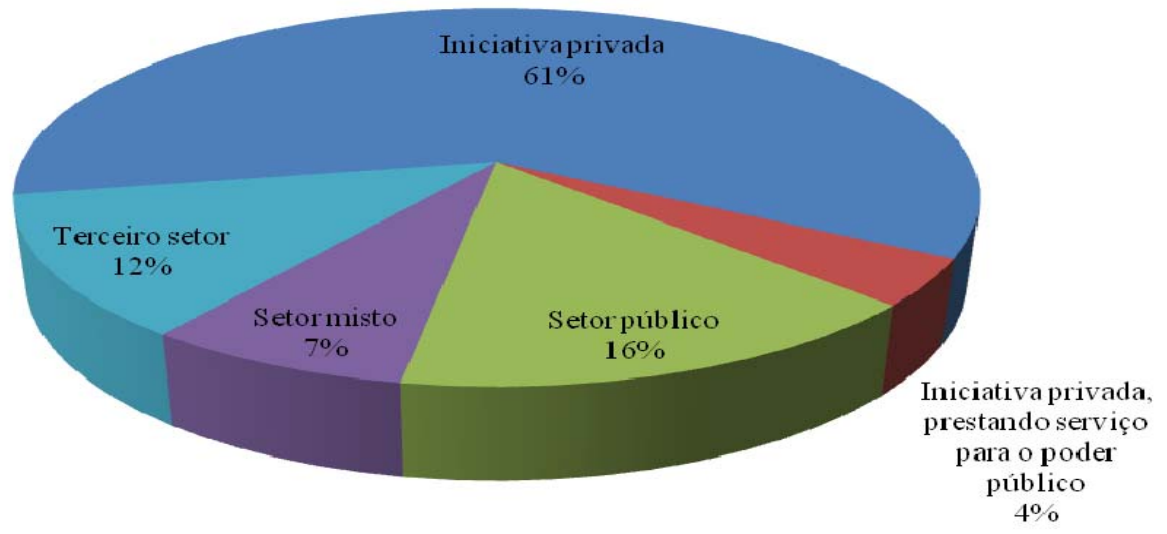

GRÁFICO 10 - NATUREZA DAS ATIVIDADES PROFISSIONAIS FONTE: WEB SURVEY, 2009. 
O turismo é considerado por autores como Lickorish e Jenkins (1997) como uma atividade da iniciativa privada, regulada pelo poder público. O gráfico 10 espelhou essa afirmação quando apontou que 61\% dos respondentes economicamente ativos estavam profissionalmente ligados à iniciativa privada. Esse número ficou mais representativo ainda ao se levar em conta os que estavam prestando serviço ao poder público e ao setor misto. Neste caso, sobrou para o poder público e para o (representativo) terceiro setor uma fatia de $28 \%$ da amostra.

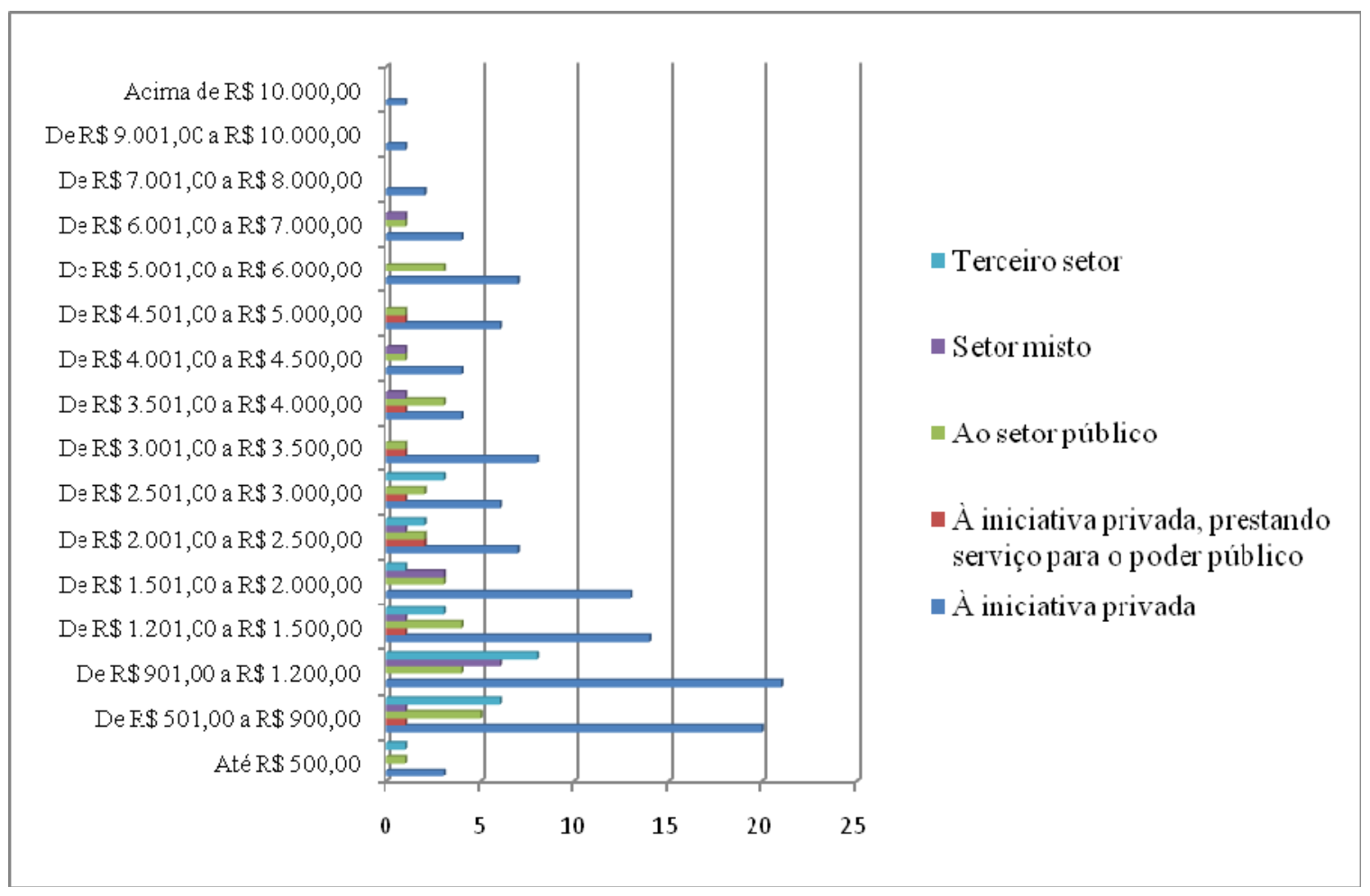

GRÁFICO 11 - FAIXAS DE REMUNERAÇÃO POR SETOR FONTE: WEB SURVEY, 2009.

Outro aspecto que se pôde constatar foi o de que a iniciativa privada se fez presente em todas as faixas de remuneração, mas que os setores público e misto, na amostra estudada, chegaram até o patamar entre $\mathrm{R} \$$ 6.000,00 e $\mathrm{R} \$ 7.000,00$, 3\% no setor público e $7 \%$ no misto. Além disso, chamou atenção especialmente o fato do terceiro setor estar no patamar remuneratório de $\mathrm{R} \$ 3.500,00$ para baixo, com 58\% declarando estar entre R\$501,00 e R\$1.200,00. 


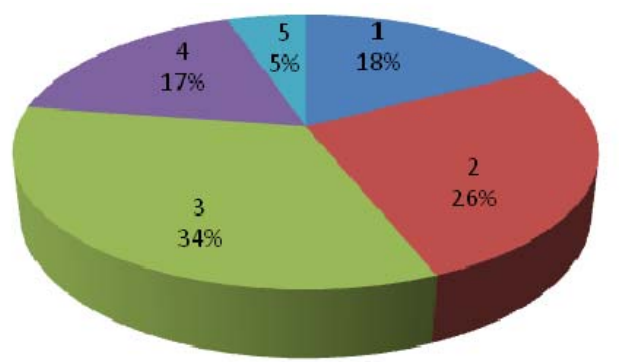

GRÁFICO 12 - SATISFAÇÃO COM RELAÇÃO À ATIVIDADE PROFISSIONAL FONTE: WEB SURVEY, 2009.

Este gráfico de número 12 mostra o nível de satisfação dos pesquisados com relação a suas atividades profissionais. Ressaltando que “1” significa muito satisfeito e “5” muito insatisfeito, percebe-se que a maioria se manteve num nível intermediário de satisfação, com tendência ao positivo.

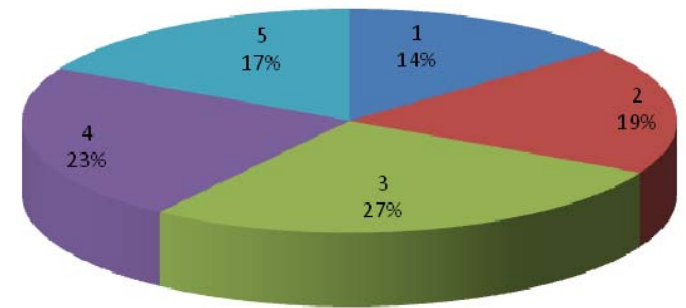

GRÁFICO 13 - SATISFAÇÃO EM RELAÇÃO A TER CURSADO TURISMO FONTE: WEB SURVEY, 2009.

Aqui já se pôde perceber uma tendência pelas respostas negativas ligadas à insatisfação com a formação, que superaram a neutralidade $(1=$ muito satisfeito; 5 = muito insatisfeito). Poucos respondentes fizeram uso do espaço reservado para comentários no formulário, mas dos que escreveram, muitos o fizeram criticando a profissão, o mercado de trabalho e as baixas remunerações.

\section{BLOCO III - ATUAÇÃO EM PLANEJAMENTO TURÍSTICO}

O Planejamento Turístico figura como uma das áreas de atuação do turismólogo e sempre esteve entre as áreas de maior especialização. Entretanto, pouco ainda se sabe sobre a atuação dos egressos nessa área. 


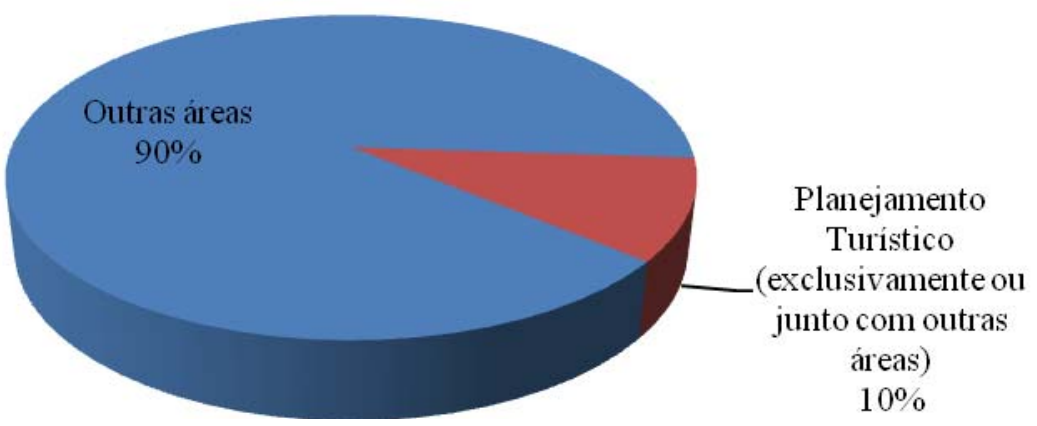

GRÁFICO 14 - PERCENTUAL DOS EGRESSOS QUE MENCIONARAM TRABALHAR COM PLANEJAMENTO (EXCLUSIVAMENTE OU EM CONJUNTO COM OUTRAS ÁREAS)

FONTE: WEB SURVEY, 2009.

Os dados aqui levantados apontaram para número semelhante aos levantados na Espanha (ANECA, 2005), já da amostra estudada somente 10\% responderam trabalhar com planejamento turístico, exclusivamente ou em conjunto com outra área, indo ao encontro dos dados levantados por eles em relação à área.

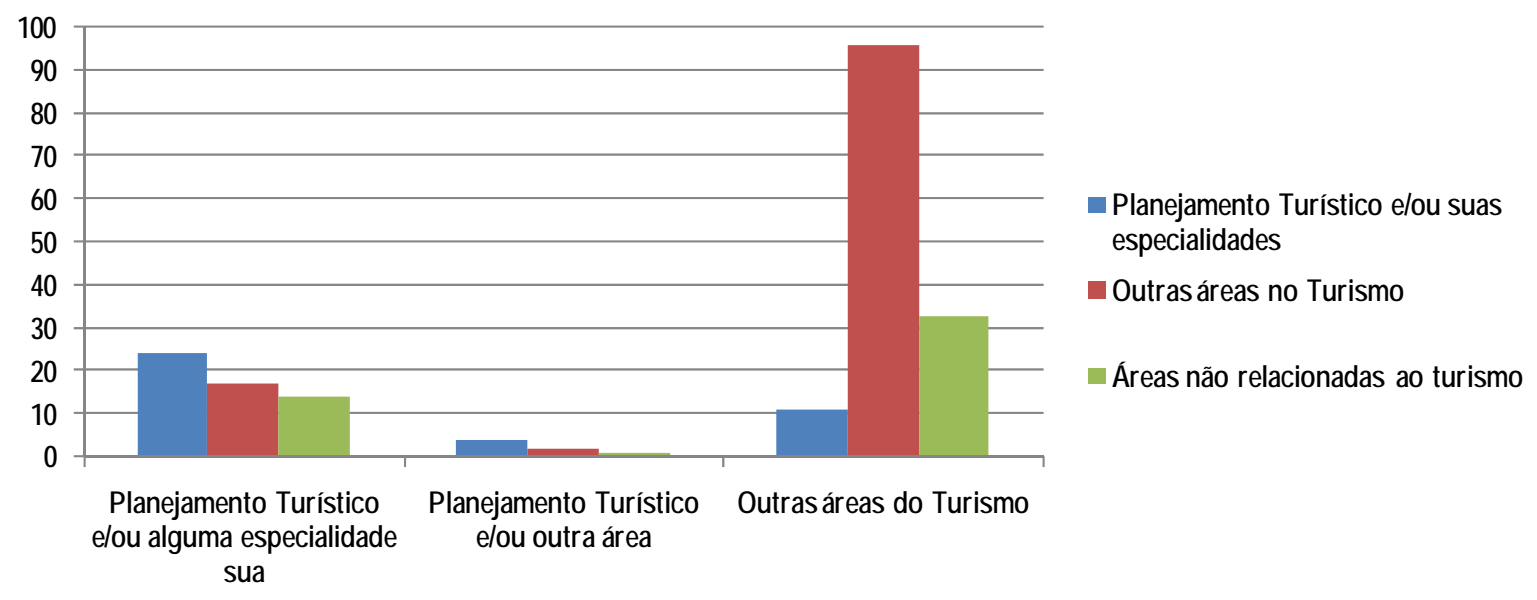

GRÁFICO 15 - EM QUE ÁREA IMAGINAVAM TRABALHAR ENQUANTO ESTAVAM NA FACULDADE E ONDE AINDA PRETENDIAM TRABALHAR FONTE: WEB SURVEY, 2009.

Perguntou-se aos respondentes em que área tinham a intenção de trabalhar no futuro (eixo horizontal) na época em que estavam na faculdade, e momento da pesquisa, considerando a experiência pessoal de cada um, em qual ainda gostariam de trabalhar, como apresentado na legenda. A divisão em três blocos de respostas mostra, no eixo horizontal, os que desejavam trabalhar em planejamento turístico e/ou outra área. Contatou-se que a migração dos que desejavam planejamento para outras áreas foi maior do que o inverso. 


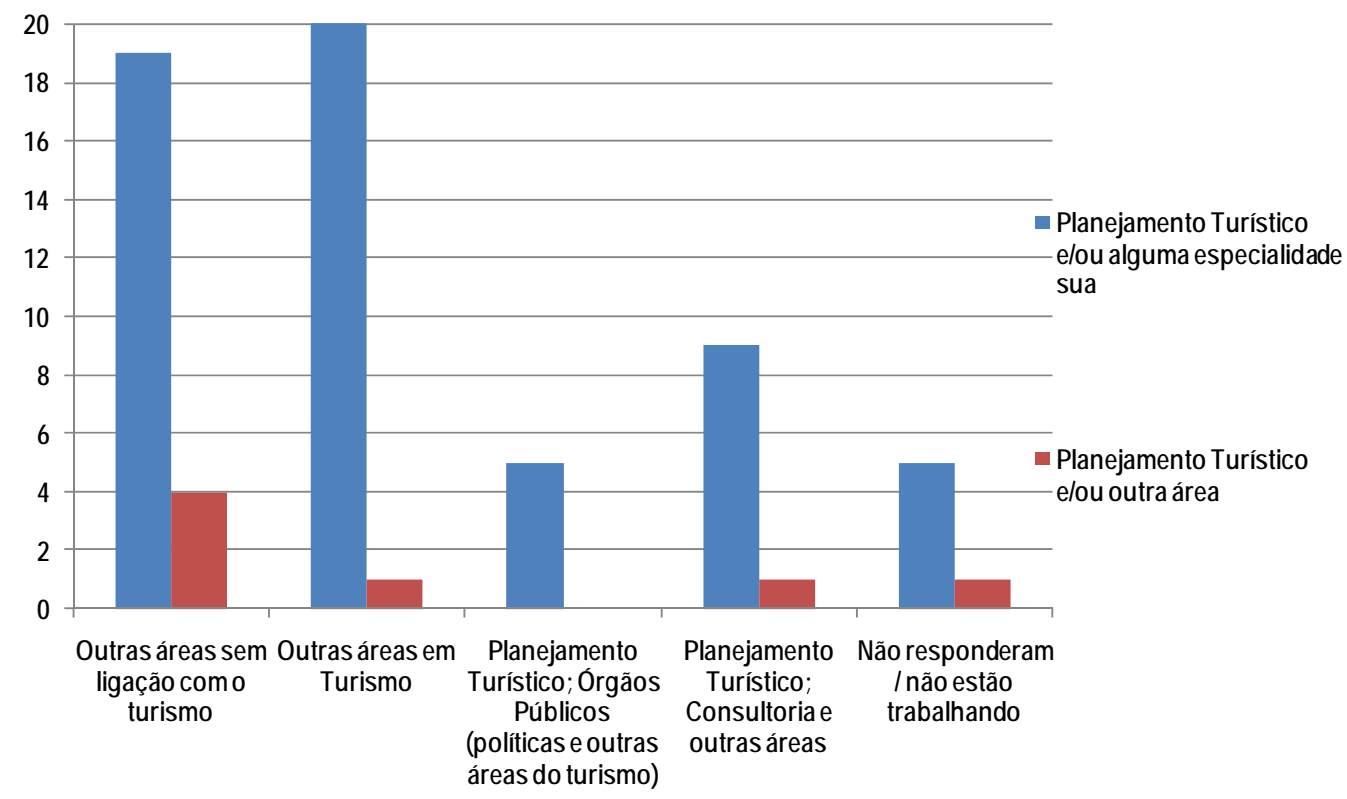

GRÁFICO 16 - COM O QUE TRABALHAVAM OS QUE INTENCIONAVAM TRABALHAR COM PLANEJAMENTO

FONTE: WEB SURVEY, 2009.

Dos que mencionaram ter a intenção de trabalhar com Planejamento e/ou alguma especialidade pessoal (azul), a grande maioria mencionou estar trabalhando em outra área e uma parcela representativa foi para a consultoria. Os que pensavam em Planejamento e mais outras áreas distribuíram-se por várias áreas, exceto setor público.

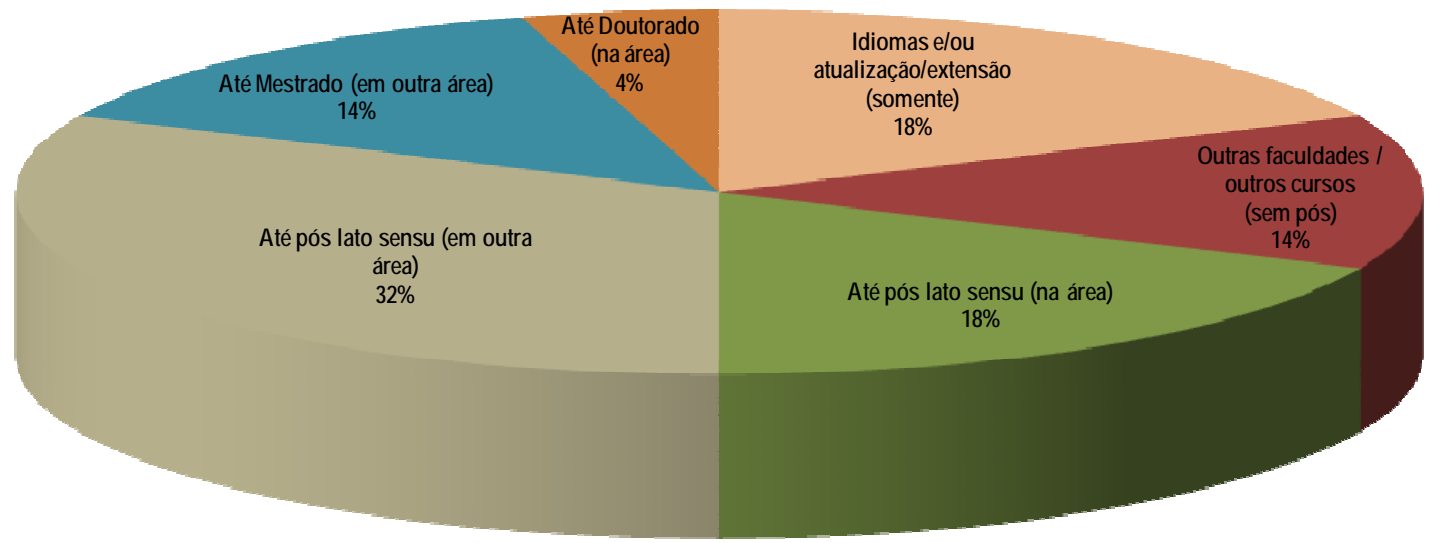

GRÁFICO 17 - NÍVEL DE FORMAÇÃO DE QUEM TRABALHAVA COM PLANEJAMENTO (EXCLUSIVAMENTE OU JUNTAMENTE COM OUTRAS ÁREAS)

FONTE: WEB SURVEY, 2009. 
Percebe-se neste gráfico que, entre os que foram efetivamente trabalhar com Planejamento (exclusivamente ou não) houve uma proporção quase que exata entre os que não fizeram nenhum tipo de pós-graduação e a soma dos que fizeram stricto sensu (mestrado e doutorado). A grande maioria, entretanto, cursou lato sensu (especialização), sendo a maioria em outra área.

Perguntou-se, por fim, aos que mencionaram trabalhar com Planejamento Turístico, com que outras áreas também trabalhavam e qual suas faixas de renda final. Algumas áreas pareceram combinar bastante tanto com o que se considera Planejamento, originalmente, quanto com o que se convencionou chamar de área Planejamento, que inclui Consultoria de Destinos Turísticos ou até Órgãos Oficiais de Turismo.

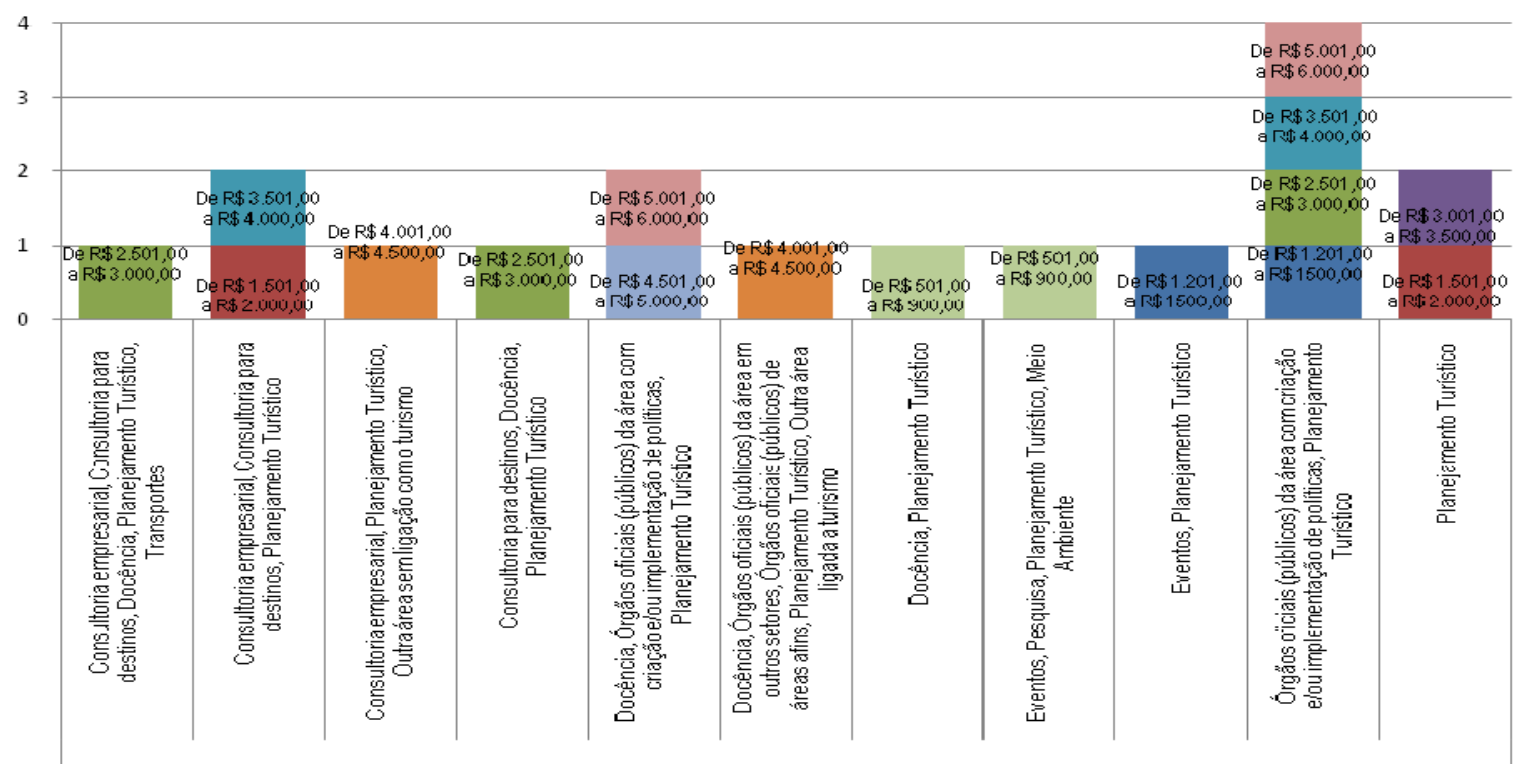

GRÁFICO 18 - RENDA DOS QUE TRABALHAVAM COM PLANEJAMENTO TURÍSTICO EXCLUSIVAMENTE OU EM CONJUNTO COM OUTRAS ÁREAS FONTE: WEB SURVEY, 2009.

Observou-se que, ao contrário do que ocorreu na área de turismo de forma ampla em gráficos anteriores, os maiores salários estavam posicionados em categorias que agregavam outras atividades (como consultoria e docência) com atividade no setor público. 


\section{CONSIDERAÇÕES FINAIS}

A pesquisa realizada para este artigo reiterou algumas impressões empíricas sobre os cursos de turismo, como o aumento da remuneração diretamente proporcional ao tempo de formado e ao nível de formação, a concentração da mão-de-obra na iniciativa privada e a predominância do público feminino. Revelou também, entretanto, dados novos que esclareceram alguns pontos que continuam sendo alvo de curiosidade acerca da profissão, como satisfação profissional e faixa de remuneração abrangente da iniciativa privada e não tão alta no terceiro setor, além de mostrar a tendência de permanência no local de formatura e de desmitificar a suposta tendência de turismólogos se formarem e migrarem para o exterior.

Como seria de se esperar, os cursos que mais tiveram respondentes foram os que mais estavam formando turismólogos em Curitiba, sendo a UP no setor privado e a UFPR do setor público. A grande maioria dos respondentes foi originalmente de Curitiba, e tanto entre esses quanto entre os que migraram para estudar, a maioria permaneceu em Curitiba depois de formado.

Ainda no bloco de perfil profissional, evidenciou-se a tendência a baixos salários, o que já era uma realidade conhecida informalmente. Respondentes que mencionaram receber até $\mathrm{R} \$ 1.500,00$ dominaram a amostra ficando com 56\% e a principal faixa salarial é a que se posicionou entre R\$ 901,00 a R\$1.200,00. Notou-se que o tempo pós-colação de grau influenciou positivamente nos salários, o que veio ao encontro da área em ainda valorizar o tempo de serviço mais do que a formação propriamente dita. Há também a interpretação possível de que as pessoas formadas há mais tempo tenham tido mais oportunidade de continuar seus estudos e que a formação continuada se refletiu em seus salários.

O segundo bloco foi direcionado ao conhecimento sobre as impressões dos turismólogos logo após sua formatura, já que se supunha uma presumível dificuldade de inserção profissional. Notou-se que em função da maior parte das vagas nesses cursos serem noturnas, muito alunos estavam trabalhando durante a graduação. Nesse sentido, 54\% dos que assim o responderam afirmaram que nos primeiros meses pós-formatura permaneceram onde ou com o que já trabalhavam, e que 43\% já estavam trabalhando na área de turismo quando saíram da faculdade, o que remete à possibilidade de abertura de 
mercado advinda dos estágios e até de haverem sentido necessidade de ingressar num curso superior de Turismo após seu contato com o mercado de trabalho. Vale ressaltar, contudo, que a quantidade de pessoas que permaneceu em empregos fora do turismo ou que começou a trabalhar em outras atividades também poderia estar apontando para uma saturação de mercado.

Havia certa expectativa dos autores em evidenciar que os bacharelados em turismo enviariam muitos egressos para o exterior, o que não foi percebido nessa amostra, já que somente 8\% deles afirmaram ter ido para o exterior logo após terem se formado. Na verdade houve mais respondentes que afirmaram ter continuado estudando, inclusive outras graduações. Em termos de remuneração, percebeu-se que sua melhoria não ocorreu somente com o tempo após a formatura, como mencionado anteriormente, mas em especial, com a continuidade nos estudos. Como foi mostrado no artigo, as maiores remunerações, ainda que em menor freqüência, estiveram relacionadas aos que tinham maior nível de formação na área, ainda que existisse uma variação significativa de faixas salariais em cada categoria, o que poderia estar indicando um mercado pouco inclinado a vincular a remuneração ao nível de formação. A iniciativa privada esteve presente em todas as faixas de remuneração e o fato de $61 \%$ dos respondentes economicamente ativos estarem ligados à iniciativa privada, confirmou também uma informação que praticamente faz parte do senso comum.

O bloco final da pesquisa focou na atuação profissional em Planejamento Turístico e apontou que $10 \%$ dos turismólogos que a responderam mencionaram trabalhar com Planejamento Turístico exclusivamente ou em conjunto com outras áreas e atividades. Evidenciou-se na comparação das respostas sobre em que área intencionavam trabalhar no futuro, na época em que estavam na faculdade, e na época da pesquisa, considerando a experiência pessoal de cada um, em qual ainda gostariam de trabalhar, demonstrando que a migração dos que desejavam planejamento para outras áreas foi maior do que o inverso. Tal constatação poderia estar indicando a possibilidade do Planejamento Turístico ser mais promissor como área de estudo, no círculo acadêmico, do que como área de atuação profissional. Constatou-se que freqüentemente planejadores eram também professores e que trabalhavam geralmente com outras áreas, algumas das quais pareceram combinar bastante tanto com o que se considera Planejamento, originalmente, quanto com o que se convencionou chamar de área de 
Planejamento, que inclui Consultoria de Destinos Turísticos ou até Órgãos Oficiais de Turismo. Apontou ainda, que os maiores salários estavam posicionados em categorias que conjugavam outras atividades, com destaque para o setor público. Entretanto, a combinação exclusiva de Planejamento e Docência foi a que gerou relatos de menores faixas salariais entre os planejadores respondentes, o que poderia ter relação direta com outro dado que chamou a atenção, que, entre os que foram efetivamente trabalhar com Planejamento (exclusivamente ou não), 18\% não havia feito nenhum tipo de pósgraduação e a soma dos que fizeram pós-graduação stricto sensu (mestrado e doutorado) forneceu o mesmo percentual. Metade da amostra, entretanto, fez pós-graduação lato sensu (especialização), sendo a maioria em outra área que não a de turismo. Isso supostamente se reflete na remuneração do planejador-docente, já que as faixas de remuneração na academia tendem a ser vinculadas à titulação dos professores. Ressaltase ainda, que ambas as atividades (docência e planejamento) demandam tempo e dedicação, e sua combinação dificulta, inclusive, a possibilidade de formação continuada.

A principal limitação da pesquisa foi a falta de dados consistentes a respeito da quantidade de egressos dos cursos superiores de turismo de Curitiba, o que impossibilitou a determinação da margem de erro exata e do tamanho apropriado da amostra. Esta amostra, também, foi uma das limitações da pesquisa, já que foi baseada em listas de e-mails e na distribuição de respostas voluntárias por parte dos respondentes.

Em termos de alcances, pode-se considerar que o trabalho traz à tona temas que são relevantes tanto para o estudo do turismo, principalmente em nível de graduação, quanto para o mercado de trabalho com ênfase na atuação de turismólogos como planejadores de turismo. O enfoque desta pesquisa mostra-se inovador, já que mesmo sendo o Planejamento Turístico uma das áreas mais tradicionais na formação de turismólogos, não se tem notícia de estudos anteriores que levantassem dados de atuação profissional na área.

O artigo não tem a pretensão de encerrar o tema, mas já trouxe apontamentos para um questionamento sobre o ensino de Planejamento Turístico, considerando que poucos turismólogos efetivamente estavam atuando na área e que a procura por essa atividade parece ser mais promissora enquanto se está cursando os bacharelados do que 
no mercado de trabalho. Assim, abre-se espaço para novas pesquisas que poderão ser realizadas tanto na forma de estudos comparativos em outras regiões do Brasil, a fim de obter mais subsídios para verificar se há distorções entre a formação na área e as possibilidades profissionais, como comparações com outras atividades profissionais e outras carreiras. Além disso, pesquisas sobre a eficácia na formação de docentes para o turismo e da própria relação da academia com o planejamento de destinos turísticos poderão indicar novos rumos para a formação e a atuação profissional dos egressos de bacharelados em turismo.

\section{REFERÊNCIAS}

AIREY, D; TRIBE, J. An International Handbook of Tourism Education. Elsevier: Oxford, Inglaterra, 2005.

ALMEIDA, M. V. O Ensino de Planejamento Turístico no Brasil: reflexões e recomendações para a prática pedagógica. In: RUSCHMANN, D; SOLHA, K. T. (Orgs.) Planejamento Turístico. Barueri: Manole, 2005.

ANECA - Agencia Nacional de Evaluación de la Calidad y Acreditación. Libro Blanco: Título de Grado en Turismo. Ministerio de Educación y Ciencia, España, 2005.

BARRETTO, M. Planejamento responsável do turismo. Campinas, SP: Papirus, 2005.

BENI, M. C. Análise estrutural do turismo. 5. ed. São Paulo: Senac, 2001.

CALDUCH CERVERA, R. Dinámica de la Sociedad Internacional. Editorial Ramón Areces: Madrid, 1993.

DENCKER, A. Pesquisa em Turismo: planejamento, métodos e técnicas. 9. ed. São Paulo: Futura, 2007.

LICKORISH, L. J.; JENKINS, C. L. An Introduction to Tourism. Oxford: Butterworth-Heinemann, 1997.

MACHADO, F. Atuação profissional dos egressos dos cursos de Turismo: estudo de caso em uma Instituição de Ensino Superior de Belo Horizonte. In: AGUIAR, M. de F.; BAHL, M. (Orgs.) Competência Profissional no Turismo e Compromisso Social. São Paulo: Roca, 2006. 
MATIAS, M. Panorama da formação profissional em turismo e suas relações com o mercado de trabalho no Brasil. In: TRIGO, L. G. G. (Org.) Análises regionais e globais do turismo brasileiro. Roca, São Paulo, 2005.

MINTZBERG. H. Ascensão e queda do planejamento estratégico. Porto Alegre: Bookman, 1999.

MUNUERA ALEMÁN, J. L.; RODRÍGUEZ ESCUDERO, A. I. Marketing estratégico: teoría y casos. Madrid: Ediciones Pirámide, 1998.

OMT - ORGANIZACIÓN MUNDIAL DEL TURISMO. Introducción al turismo. Madrid: OMT, 1998.

. Agenda para planificadores locales: turismo sostenible y gestión municipal, edición para América Latina y Caribe. Madrid: OMT, 1999.

REA, L.; PARKER, R. Metodologia da Pesquisa: do planejamento à execução. São Paulo: Pioneira Thompson Learning, 2002.

SILVEIRA, C. E.; GÂNDARA, J. M. G.; MEDAGLIA, J. A disciplina de Planejamento Turístico no Ensino Superior de Turismo: das influências aos novos desafios. Revista Brasileira de Pesquisa em Turismo, v. 2, n. 1, p. 113-133, mar. 2008.

SPINELLI, S. A Importância da Formação Profissional em Turismo. In: SHINUGOV NETO, A; MACIEL, L. (Orgs.) Currículo e Formação Profissional nos Cursos de Turismo. Campinas: Papirus, 2002.

VALLS, J.-F. Las claves del mercado turístico. Bilbao: Deusto, 2000.

Recebido em: 30/05/2010.

Aprovado em: 30/06/2010. 